\title{
Precipitation Spatial Patterns in Cities with Different Urbanisation Types: Case Study of Novi Sad (Serbia) as a Medium-sized City
}

\author{
Stevan Savić ${ }^{A}$, Mathias Kalfayan ${ }^{B}$, Dragan Dolinaj ${ }^{A}$ \\ Received: February 13, 2020 | Revised: May 04, 2020 | Accepted: May 09, 2020 \\ doi: 10.5937/gp24-25202
}

\begin{abstract}
A direct outcome of the global climate change is the modification of seasonal precipitation patterns, apparent on a monthly temporal scale. In Central Europe, it includes more frequent high-intensity rainfalls, occurring mostly during spring and summer. These heavy rainfalls induce pluvial floods in urban areas due to a high percentage of impervious surfaces and limited drainage systems. This hazard affects Central European cities and impacts many receptors, including lives, infrastructures, private properties or the functioning of cities. This study focuses on the monitoring of precipitation events with the aim of revealing precipitation patterns across two different types of land cover: urban and suburban/rural areas of Novi Sad (Serbia). Measurements from seven rain gauge stations were used as input data, covering the 2015-2018 period. The precipitation data were analysed using 12 precipitation indices, nine of which were defined by the Expert Team on Climate Change Detection and Indices (ETCCDI), while three additional were designed specifically for this study. Based on their locations, the stations were classified into the 'urbanized' and 'non-urbanised' group.

The concept of the Local Climate Zone (LCZ) was used to classify urbanised areas LCZ1-8, non-urbanised areas LCZ9 and the land cover zones (LCZ A-G). A statistical analysis based on the ANOVA F-test was conducted, defining the significance threshold at $90 \%$ for $\alpha=0.01$ and at $95 \%$ for $\alpha=0.05$. The obtained results revealed one relation for the CDD index at $95 \%$ and two relations at $90 \%$ for CDD and Rp95 indices, showing a relation between heavy rainfall and the type of land cover. Statistical results underline the need for a denser station network and longer monitoring periods in order to proceed to stronger statistical tests and make it possible to establish other relations with the climate indices.
\end{abstract}

Keywords: urban climate; heavy rainfall; monitoring network; precipitation indices; pluvial flood; Novi Sad

\section{Introduction}

Human civilisations have shown important transformations over the past several decades, in terms of organisation and development. The growing human demography and urbanization are important factors shaping the current functioning of our urban systems.
The world's population already hit seven billion in 2011; $75 \%$ of the European population live in cities today (Richard, 2002; Swart et al., 2012) and it is expected that around $80 \%$ of the world's population will live in cities by 2025 (UNFPA, 1999; WMO, 2008). Cities

\footnotetext{
A University of Novi Sad, Faculty of Sciences, Climatology and Hydrology Research Centre, Serbia; stevan.savic@dgt.uns.ac.rs; dragan.dolinaj@dgt.uns.ac.rs

в Warsaw University of Life Sciences, Department of Civil Engineering, Poland; mathias.kalfayan@gmail.com

* Corresponding author: Stevan Savić, e-mail: stevan.savic@dgt.uns.ac.rs
} 
and towns are getting denser with the constant extension of urban limits, in parallel with the intensive conversion of natural land into agricultural or industrial areas. These trends are often unsustainable and they induce deep perturbations in various parts of natural macrosystems, such as climate, biotopes, or resources.

In parallel, the recent crisis related to climate change is becoming more severe. Changes on Earth and the place for human settlements arise as new issues. The current climate change is associated with a significant temperature increase at a global scale, due to human activities, especially since the early industrial period in the previous century (Allen et al., 2018). It has been identified as one of the main drivers of climatic perturbation, by changing the existing pattern of hydrological functioning (IPCC, 2007; Jiang et al., 2018).

Rainfall and extreme rainfall precipitations are recurring natural climatic events, with different return periods and magnitudes (Neppel et al., 1997). They are impacted by the global climate change and they occur more intensively, revealing new climate forcing (Gaume et al., 2009). They may be responsible for pluvial flooding due to the great amount of water carried by them and the small spatial and temporal scale of their occurrence (Collier, 2007; Gaume et al., 2009), which make these hazards very difficult to forecast.

Nowadays, a significant rise of heavy precipitation at continental (Groisman et al., 2004) and global scales (Groisman et al., 2005) has already been observed worldwide in different climate contexts. It inevitably leads to a more frequent occurrence of urban pluvial flooding, also known as flash flood. Furthermore, certain seasonality and geographical variability of flash flood have been detected at the European scale (Trobec, 2017; Prokić et al., 2019). This hazard is the most recurrent in the Mediterranean region, mostly in autumn, and in continental climate, especially in spring or summer months (Gaume et al. 2009; Marchi et al., 2010; Swart et al., 2012; Guerreiro et al., 2017).

Keeping in mind the new scale and intensity of these phenomena, and the consequent rise of receptors exposed to flash flood risks, it is necessary to understand better extreme rainfall generation and its place in the environment. Thousands of additional people are likely to be exposed to the risk of pluvial flooding in the coming decades (Ciscar et al., 2011; EEA, 2012). Intensive research is being conducted, especially in Europe, Asia and USA, because the monitoring and analysis of such events is a cornerstone of flash flood analysis and forecasting (Borga et al., 2002).

Accordingly, this study analyzes possible urban land cover/surface factors impacting the variability of extreme precipitation events by establishing climatic (precipitation) indices (Zhang et al., 2011), suggesting that it should be brought into relationship with the pluvial flood hazard according to the historical events occurring in the region. Climatic measurements have been carried out in Novi Sad (Serbia), using a set of meteorological station sensors which recorded precipitation data over several years.

The research on extreme precipitation events and pluvial floods, as well as meteorological studies, plays an important role in gaining knowledge and understanding new climatic events and their impact on human societies. Thy seeks to find an adaptive way to face natural hazards, by adopting a holistic approach focused on reaching sustainability (Xia et al., 2017; Jiang et al., 2018). This gives rise to new concepts, e.g. sponge cities, or an integrated framework and policy implementation. The territorial development of human settlements and the evolution of human societies should adapt to the environment by increasing the resilience of our civilization.

\section{Description of the urban area, used data and statistical methods}

Novi Sad is the second largest city in Serbia. It has approximately 332,000 inhabitants who are living in a built-up area reaching102 $\mathrm{km} 2$ in size (Statistical Office of the Republic of Serbia, http://www.stat.gov.rs). This urban area is located in Central Europe, in the Carpathian plain. Its northern part is located on an elevation ranging between 72 and $80 \mathrm{~m}$ in height, while the elevations in its southern part range between 80 and $200 \mathrm{~m}$ (Petrovaradin and Sremska Kamenica suburban towns). The Danube River flows along the eastwest axis in the southern part of Novi Sad (260-680 m wide), and the narrow Danube-Tisza-Danube Canal runs through the city along the northwest-southeast axis, flowing into the Danube.
The areas surrounding the urban core of Novi Sad to the north, east and west mainly include agricultural land. The main feature of the southern section is the Fruška Gora National Park, natural area with low mountains covered with a deciduous forest. According to the Köppen-Geiger climate classification (Kottek et al., 2006), the Novi Sad region has a Cfb climate (temperate climate, fully humid, warm summers, with at least four Tmon $\geq+10^{\circ} \mathrm{C}$ ). The mean monthly air temperature ranges from $-0.3{ }^{\circ} \mathrm{C}$ in January to $21.8{ }^{\circ} \mathrm{C}$ in July. The mean annual precipitation is $623 \mathrm{~mm}$ (based on data collected between 1949 and 2015). Furthemore, the research of Milošević and Savić (2013) shows positive precipitation trends dur- 
ing all seasons (except winter), as well as on the annual level, for Novi Sad, in the 1949-2010 period. The temperature and precipitation data were provided by the Meteorological Yearbooks of the Republic Hydrometeorological Service of Serbia.

Novi Sad's urban area is marked by districts of different urban types and sizes. The central area is densely built-up. It consists of mid-rise blocks (usually four to eight floors high), and only a few of them reach 1618 floors. The surroundings parts of the city are mainly composed of residential areas. There is an electrical production plant in the northern suburban area and much of the city's warehousing can be found there, intermixed with low-rise residential housing. The main avenues and boulevards link various districts, whereas moderately wide streets serve as communications within the built-up area. A number of parks act as open spaces in the downtown, while mature trees (more than 30 years old) form the green infrastructure along several main avenues of Novi Sad (Geletič et al., 2019). In addition, the Danube and its densely vegetated river banks provide a valuable ecological corridor inside the urban area. More open vegetated areas and natural places can be found on the outskirts.

The landscape classification used for Novi Sad's urban area consists of 17 standard Local Climate Zones (LCZs), developed by Stewart and Oke (2012). The standard set is divided into ten built-up types (from 1 to 10) and seven land cover types (from A to G). Two different GIS-based LCZ mapping methods were ap- plied for the city of Novi Sad in previous research: the Lelovics-Gál method (Lelovics et al., 2016) and the Geletič and Lehnert method (Geletič \& Lehnert, 2016). Thirteen LCZs were defined and delineated in Novi Sad and its surroundings using the two methods: seven built-up and six land cover types. The delineated built-up LCZs are: compact mid-rise (LCZ 2), compact low-rise ( $\mathrm{LCZ}_{3}$ ), open mid-rise ( $\mathrm{LCZ}_{5}$ ), open low-rise (LCZ 6), large low-rise (LCZ 8), sparsely built (LCZ 9) and heavy industry (LCZ 10) (Figure 1). The delineated land cover LCZs are: dense trees (LCZ A), scattered trees (LCZ B), low plants (LCZ D), bare rock or paved (LCZ E), bare soil or sand (LCZ F) and water (LCZ G).

In this study, data collected at seven precipitation stations, located inside the urban area or in the suburban/rural part, have been used for the analysis. All precipitation stations are equipped with an OTT Pluvio2 $L$ weighing rain gauge, with the accuracy of \pm 0.1 $\mathrm{mm}$; intensity of $\pm 0.1 \mathrm{~mm} / \mathrm{min}$; measurement intervals of $1 \mathrm{~min}$, etc. All the stations are installed $1 \mathrm{~m}$ above the ground. The stations have been divided into two distinct categories based on their locations: the 'urbanised' group - stations located in dense urban areas (from LCZ1 to LCZ1o, except LCZ9), and the 'non-urbanised' group - stations located in rural and green areas (LCZ9 and LCZ from A to G). The precipitation measurements were analysed with one-minute precision, during a research period lasting from January 2015 to December 2018. The precipitation stations are part of the monitoring system of the PUC Water and Sewage Utility Novi

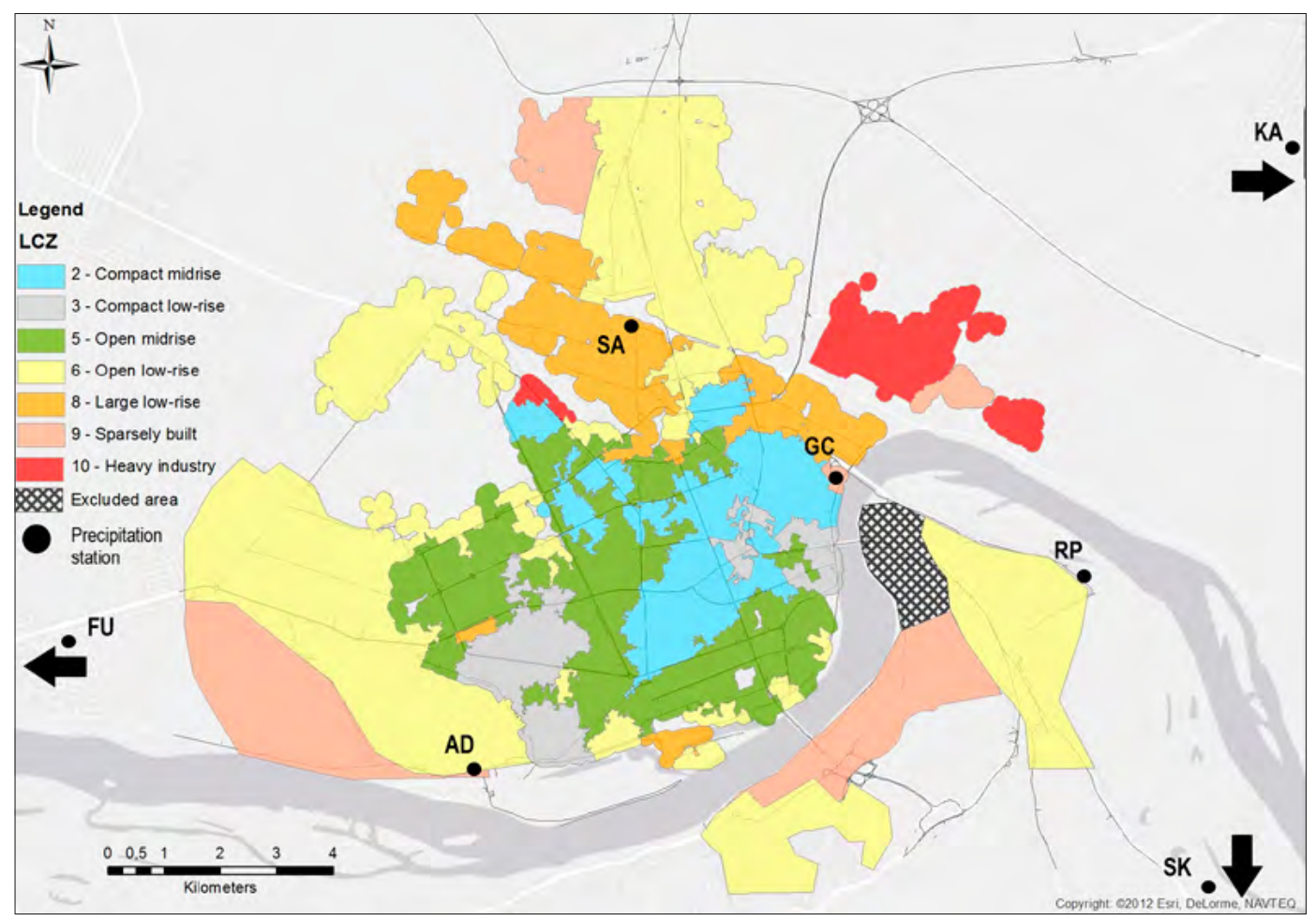

Figure 1. Urban area of Novi Sad with defined built-up LCZs and the locations of the analysed precipitation stations 
Sad (JKP Vodovod i kanalizacija Novi Sad), which provided precipitation data for the city of Novi Sad. Table 1 lists the main characteristics of the analysed stations.

In order to define precipitation characteristics and differences between 'urbanised' and 'non-urbanised' areas, 12 precipitation indices were used. The precipitation indices are recommended by the ETCCDI (Expert Team on Climate Change Detection and Indices) (Karl et al., 1999; Zhang et al., 2011), and three additional indices have been designed in this study for further analysis. Table 2 shows the selected precipitation indices used in the analysis. Detailed and precise definitions can be found on the ETCCDI/CRD Climate Change Indices website (http://etccdi.pacificclimate. org/list_27_indices.shtml). Furthermore, an ANOVA F-test was performed to investigate the relations between climatic events (climatic indices) and land cover (urbanised and non-urbanised groups). The Fisher-Snedecor tables were used with a significance threshold of $90 \%$ and $95 \%$ corresponding to an $a$ of 0.1 and 0.05 , respectively. The value $\mathrm{F}$ calculated by testing statistically each climatic index was compared to the value of F' provided in the table, with the probability a to be exceeded. The degrees of freedom were established according to the number of groups and the number of samples used. All extreme precipitation indices were calculated for the entire research period (2015-2018), as well as for each year, respectively.

Table 1. Precipitation stations and their basic geographic information. Notes: Abb - Abbreviation; Lat. - latitude; Long. - longitude; Alt. - altitude in metres; * - GC2 stands for the sewage treatment plant where the precipitation station is installed

\begin{tabular}{|c|l|c|c|c|c|l|}
\hline № & Station name & Abb. & Lat. & Long. & Alt. & Urbanisation type \\
\hline 1 & GC2 ${ }^{*}$ & GC & $45^{\circ} 15^{\prime}$ & $19^{\circ} 51^{\prime}$ & 79 & urbanised \\
\hline 2 & Adice & AD & $45^{\circ} 13^{\prime}$ & $19^{\circ} 47^{\prime}$ & 75 & urbanised \\
\hline 3 & Rokov Potok & RP & $45^{\circ} 14^{\prime}$ & $19^{\circ} 53^{\prime}$ & 77 & non-urbanised \\
\hline 4 & Sajlovo & SA & $45^{\circ} 17^{\prime}$ & $19^{\circ} 48^{\prime}$ & 83 & urbanised \\
\hline 5 & Futog & FU & $45^{\circ} 14^{\prime}$ & $19^{\circ} 42^{\prime}$ & 79 & urbanised \\
\hline 6 & Kać & KA & $45^{\circ} 18^{\prime}$ & $19^{\circ} 55^{\prime}$ & 73 & non-urbanised \\
\hline 7 & Sremski Karlovci & SK & $45^{\circ} 12^{\prime}$ & $19^{\circ} 55^{\prime}$ & 148 & non-urbanised \\
\hline
\end{tabular}

Table 2. Selected extreme precipitation indices recommended by the ETCCDI (Karl et al., 1999; Zhang et al., 2011) and additional indices used in this study (marked with an asterisk)

\begin{tabular}{|c|c|c|c|c|}
\hline № & ID & Indicator name & Indicator Definitions & Units \\
\hline 1 & TP* & Total precipitation & $\begin{array}{l}\text { Total amount of precipitation during the } \\
\text { research period }\end{array}$ & $\mathrm{mm}$ \\
\hline 2 & WD* & Number of wet days & $\begin{array}{l}\text { Number of days with precipitation } \geq 0.1 \mathrm{~mm} \\
\text { during the research period }\end{array}$ & days \\
\hline 3 & RX1day & $\begin{array}{l}\text { Max one-day precipitation } \\
\text { amount }\end{array}$ & Monthly maximum one-day precipitation & $\mathrm{mm}$ \\
\hline 4 & SDII & Simple daily intensity index & $\begin{array}{l}\text { The ratio of the total annual precipitation to } \\
\text { the number of wet days }(\geq 1 \mathrm{~mm})\end{array}$ & $\mathrm{mm} /$ day \\
\hline 5 & R10 & $\begin{array}{l}\text { Number of heavy } \\
\text { precipitation day }\end{array}$ & Annual count when precipitation $\geq 10 \mathrm{~mm}$ & days \\
\hline 6 & R20 & $\begin{array}{l}\text { Number of very heavy } \\
\text { precipitation days }\end{array}$ & Annual count when precipitation $\geq 20 \mathrm{~mm}$ & days \\
\hline 7 & CDD & Consecutive dry days & $\begin{array}{l}\text { Maximum number of consecutive days when } \\
\text { precipitation }<1 \mathrm{~mm}\end{array}$ & days \\
\hline 8 & CWD & Consecutive wet days & $\begin{array}{l}\text { Maximum number of consecutive days when } \\
\text { precipitation } \geq 1 \mathrm{~mm}\end{array}$ & days \\
\hline 9 & R90 * & Wet days & $\begin{array}{l}\text { Annual total precipitation from days }>90^{\text {th }} \\
\text { percentile }\end{array}$ & $\mathrm{mm}$ \\
\hline 10 & R95p & Very wet days & $\begin{array}{l}\text { Annual total precipitation from days }>95^{\text {th }} \\
\text { percentile }\end{array}$ & $\mathrm{mm}$ \\
\hline 11 & R99p & Extremely wet days & $\begin{array}{l}\text { Annual total precipitation from days }>99^{\text {th }} \\
\text { percentile }\end{array}$ & $\mathrm{mm}$ \\
\hline 12 & PRCPTOT & $\begin{array}{l}\text { Annual total wet-day } \\
\text { precipitation }\end{array}$ & Annual total precipitation from days $\geq 1 \mathrm{~mm}$ & $\mathrm{~mm}$ \\
\hline
\end{tabular}




\section{Results}

The quality control step revealed some atypical and extreme values for several stations. For the RP station, measurements were not recorded during the spring and summer of 2016 (from March $8^{\text {th }}$ to July $25^{\text {th }}$ ). This break of 140 days can have a serious impact on the results. Errors are especially apparent for the TP and WD indices (336.6 $\mathrm{mm}$ and 87 days), which are significantly lower than for the other stations. In order to be able to use data from this station in the analysis, an interpolation step was performed using the data for this same period collected at the other stations. Corrections were made for the TP, WD, R10, R20, CDD and PRCPTOT indices by calculating the average value for all the other stations for the same period. Moreover, suspicious data were noticed in the KA station for 2016 and 2017, especially for the TP, WD, CWD and PRCPTOT indices. The values appeared to be extremely high, compared to the other stations. An excessive amount of precipitation was recorded without knowing its origin. In this case, it was not possible to estimate precisely whether the station functioned properly and in which periods it malfunctioned. Accordingly, the KA station was excluded from further analysis. Table 3 shows the index values for all seven precipitation stations, for the 2015-2018 period. The presented data seek to show different parameters of extreme precipitation events for each year, as well as the overall situation during the four-year monitoring period.

Figure 2 shows the exponential distribution of daily precipitation for the entire research period. The data are summarized from all precipitation stations. Outcomes in the graph show that precipitation values from 0.1 to $1.0 \mathrm{~mm}$ are the most frequent. Towards higher precipitation values the frequency rapidly decreases, and between $38.1 \mathrm{~mm}$ and $90.1 \mathrm{~mm}$, the frequencies are 3, 2, 1 or o.

A statistical approach, based on the ANOVA Ftest, was run to estimate the results in terms of significance. An ANOVA single parameter test was run (Table 4) with the aim of measuring the variance of two different precipitation station groups based on land cover, i.e. 'urbanised' and 'non-urbanised'. Therefore, the aim of this study was to check the potential impact of land cover on the previously calculated climatic indices.

The results obtained using the ANOVA single factor test revealed one relation for the CDD index at 95\%, and two relations for CDD and Rp95 indices at 90\%. Indeed, the $F$ values for CDD and Rp95 were 11.11 and 5.25 , respectively. Both exceeded the $F^{\prime}$ value of 3.78 with $\alpha=0.1$ and only the CCD value exceeded the $F$, value of 5.99 with $\alpha=0.05$.

Table 3. Precipitation indices calculated for each station per year, for the whole research period (2015-2018)

\begin{tabular}{|c|c|c|c|c|c|c|c|}
\hline \multirow{2}{*}{ Indices } & \multirow{2}{*}{ y/st. } & \multicolumn{4}{|c|}{ 'urbanised' } & \multicolumn{2}{|c|}{ 'non-urbanised' } \\
\hline & & GC & $A D$ & SA & FU & RP & SK \\
\hline TP* & \multirow{12}{*}{2015} & 658.8 & 670.6 & 651.1 & 630.8 & 602.3 & 637.7 \\
\hline WD* & & 145 & 149 & 129 & 157 & 137 & 137 \\
\hline RX1day & & 60.1 & 62.4 & 55.2 & 80.4 & 61.6 & 73.3 \\
\hline SDII & & 4.5 & 4.5 & 5.0 & 4.0 & 4.4 & 4.7 \\
\hline R10 & & 17 & 17 & 19 & 16 & 16 & 17 \\
\hline R20 & & 6 & 6 & 5 & 4 & 5 & 6 \\
\hline CDD & & 33 & 33 & 33 & 33 & 38 & 33 \\
\hline CWD & & 7 & 7 & 7 & 7 & 7 & 7 \\
\hline R90p* & & 5.3 & 5.9 & 5.6 & 5.4 & 5.0 & 5.0 \\
\hline R95p & & 8.3 & 8.6 & 10.1 & 9.1 & 8.1 & 8.7 \\
\hline R99p & & 23.9 & 23.1 & 21.9 & 20.6 & 21.6 & 24.5 \\
\hline PRCPTOT & & 636.8 & 649.7 & 632.5 & 602.9 & 584.0 & 621.3 \\
\hline & & GC & $A D$ & SA & FU & $\mathrm{RP}$ & SK \\
\hline TP* & \multirow{5}{*}{2016} & 721.0 & 714.8 & 656.9 & 710.7 & 694.0 & 683.5 \\
\hline WD* & & 140 & 154 & 139 & 153 & 145 & 141 \\
\hline RX1day & & 33.3 & 35.8 & 31.5 & 35.9 & 32.1 & 45.8 \\
\hline SDII & & 5.1 & 4.6 & 4.7 & 4.6 & 3.9 & 4.8 \\
\hline R10 & & 24 & 22 & 21 & 24 & 21 & 22 \\
\hline
\end{tabular}




\begin{tabular}{|c|c|c|c|c|c|c|c|}
\hline \multirow{2}{*}{ Indices } & \multirow{2}{*}{ y/st. } & \multicolumn{4}{|c|}{ 'urbanised' } & \multicolumn{2}{|c|}{ 'non-urbanised' } \\
\hline & & GC & $A D$ & SA & FU & $\mathrm{RP}$ & SK \\
\hline R20 & \multirow{7}{*}{2016} & 6 & 8 & 4 & 8 & 6 & 6 \\
\hline CDD & & 34 & 34 & 34 & 34 & 38 & 34 \\
\hline CWD & & 5 & 4 & 5 & 4 & 3 & 4 \\
\hline R90p* & & 6.6 & 6.3 & 5.5 & 6.2 & 2.2 & 5.7 \\
\hline R95p & & 13.4 & 12.4 & 11.8 & 11.2 & 6.8 & 11.5 \\
\hline R99p & & 24.7 & 24.4 & 21.7 & 27.4 & 15.5 & 25.3 \\
\hline PRCPTOT & & 705.5 & 693.0 & 639.0 & 688.5 & 674.1 & 661.4 \\
\hline & & GC & $A D$ & SA & FU & $\mathrm{RP}$ & SK \\
\hline TP* & \multirow{12}{*}{2017} & 477.7 & 543.8 & 493.2 & 509.5 & 498.1 & 484.9 \\
\hline WD* & & 149 & 161 & 134 & 156 & 145 & 148 \\
\hline RX1day & & 26.6 & 41.2 & 60.4 & 34.4 & 29.0 & 26.1 \\
\hline SDII & & 3.2 & 3.4 & 3.7 & 3.3 & 3.4 & 3.3 \\
\hline R10 & & 12 & 13 & 11 & 11 & 13 & 13 \\
\hline R20 & & 1 & 4 & 3 & 3 & 2 & 2 \\
\hline CDD & & 17 & 17 & 17 & 17 & 17 & 17 \\
\hline CWD & & 4 & 4 & 5 & 4 & 4 & 4 \\
\hline R90p* & & 4.6 & 4.6 & 4.6 & 4.6 & 4.3 & 4.9 \\
\hline R95p & & 8.1 & 7.9 & 6.9 & 7.6 & 8.3 & 8.0 \\
\hline R99p & & 14.8 & 19.1 & 14.2 & 17.5 & 16.2 & 16.2 \\
\hline PRCPTOT & & 453.9 & 525.0 & 474.5 & 483.6 & 478.9 & 460.7 \\
\hline & & GC & $A D$ & SA & FU & $\mathrm{RP}$ & SK \\
\hline TP* & \multirow{12}{*}{2018} & 642.0 & 689.4 & 662.9 & 718.9 & 725.3 & 569.6 \\
\hline WD* & & 128 & 150 & 132 & 150 & 144 & 135 \\
\hline RX1day & & 47.9 & 48.6 & 71.2 & 94.0 & 55.8 & 28.8 \\
\hline SDII & & 5.0 & 4.6 & 5.0 & 4.8 & 5.0 & 4.2 \\
\hline R10 & & 18 & 19 & 15 & 19 & 17 & 17 \\
\hline R20 & & 5 & 5 & 7 & 7 & 7 & 6 \\
\hline CDD & & 28 & 24 & 24 & 24 & 24 & 35 \\
\hline CWD & & 5 & 7 & 7 & 7 & 7 & 7 \\
\hline R90p* & & 4.8 & 5.5 & 4.5 & 4.8 & 6.2 & 4.5 \\
\hline R95p & & 9.8 & 11.1 & 8.3 & 10.2 & 9.8 & 9.1 \\
\hline R99p & & 23.9 & 25.1 & 25.9 & 28.9 & 28.6 & 23.0 \\
\hline PRCPTOT & & 630.9 & 672.1 & 649.5 & 699.6 & 708.5 & 551.6 \\
\hline & \multirow{13}{*}{$\begin{array}{l}\text { TOTAL } \\
\text { (2015- } \\
2018)\end{array}$} & GC & $A D$ & SA & FU & $\mathrm{RP}$ & SK \\
\hline TP* & & 2499 & 2619 & 2464 & 2570 & 2520 & 2376 \\
\hline WD* & & 562 & 614 & 534 & 616 & 571 & 561 \\
\hline RX1day & & 60.1 & 62.4 & 71.2 & 94.0 & 61.6 & 73.3 \\
\hline SDII & & 0.024 & 0.024 & 0.029 & 0.037 & 0.028 & 0.031 \\
\hline R10 & & 71 & 71 & 66 & 70 & 67 & 69 \\
\hline R20 & & 18 & 23 & 19 & 22 & 20 & 20 \\
\hline CDD & & 34 & 34 & 34 & 34 & 38 & 35 \\
\hline CWD & & 7 & 7 & 7 & 7 & 7 & 7 \\
\hline R90p* & & 5.3 & 5.8 & 5.2 & 5.2 & 5.1 & 5.0 \\
\hline R95p & & 9.7 & 9.9 & 9.1 & 9.7 & 8.8 & 9.2 \\
\hline R99p & & 23.4 & 24.5 & 23.5 & 23.8 & 23.2 & 23.3 \\
\hline PRCPTOT & & 2427 & 2540 & 2396 & 2475 & 2445 & 2295 \\
\hline
\end{tabular}




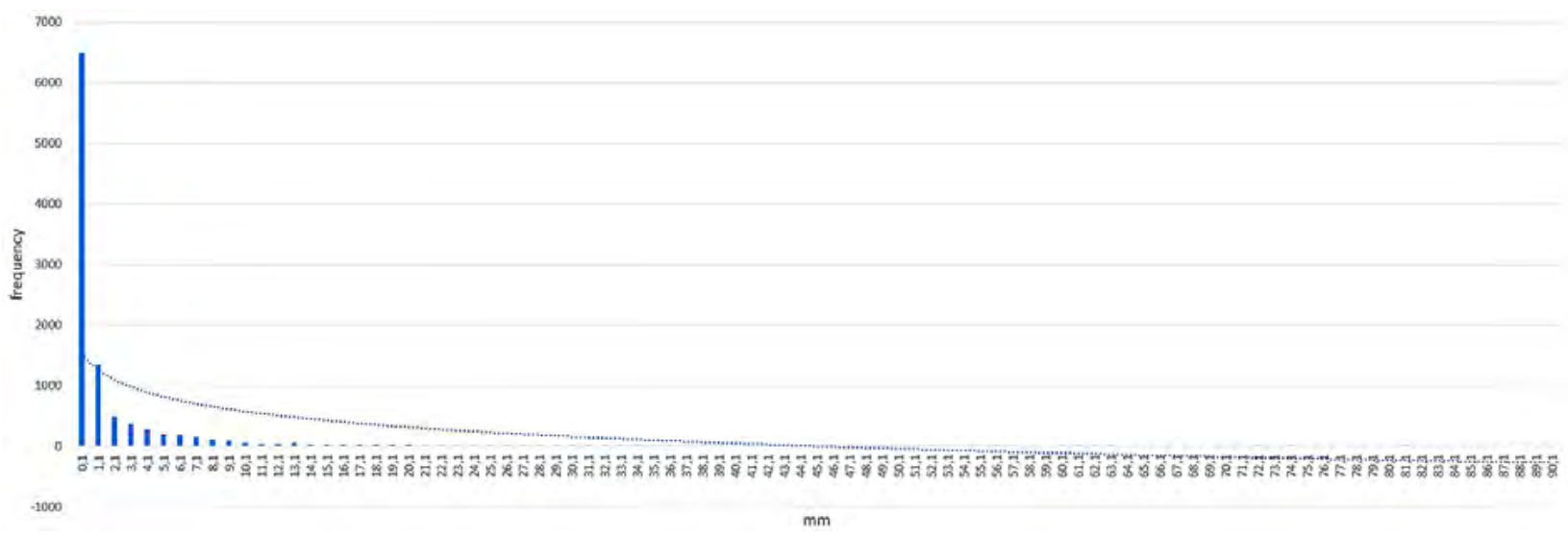

Figure 2. Inverse exponential distribution for the daily precipitations for all stations in 2015-2018

This underlines the difference for consecutive dry days and very wet days between the two different land cover groups. The other indices did not show relations although some $F$ values were close to $F^{\prime}$ values. The $F^{\prime}$ value would be lower if more groups and samples were defined.

Table 4. Outcomes of the ANOVA F-test based on the correlation between 'urbanised' and 'nonurbanised' (except the KA station) group of stations and with statistically significant threshold $\left(F^{\prime}\right)$ defined at the level of $90 \%$ and $95 \%$

\begin{tabular}{|l|c|c|c|l|}
\hline Indices & $F$ value & $F^{\prime}$ value at 95\% & $F^{\prime}$ value at $90 \%$ & Relation \\
\hline TP* & 2.63 & 5.99 & 3.78 & no apparent relation \\
\hline WD* & 0.4 & 5.99 & 3.78 & no apparent relation \\
\hline RX1day & 0.2 & 5.99 & 3.78 & no apparent relation \\
\hline SDII & 0.13 & 5.99 & 3.78 & no apparent relation \\
\hline R10 & 0.95 & 5.99 & 3.78 & no apparent relation \\
\hline R20 & 0.21 & 5.99 & 3.78 & no apparent relation \\
\hline CDD & 11.11 & 5.99 & 3.78 & relation at 90\% and 95\% \\
\hline CWD & 0.0 & 5.99 & 3.78 & no apparent relation \\
\hline R90p* & 3.53 & 5.99 & 3.78 & no apparent relation \\
\hline R95P & 5.25 & 5.99 & 3.78 & relation at 90\% \\
\hline R99P & 2.86 & 5.99 & 3.78 & no apparent relation \\
\hline PRCPTOT & 2.74 & 5.99 & 3.78 & no apparent relation \\
\hline
\end{tabular}

\section{Discussion and concluding remarks}

It is largely admitted that heavy rainfall intensification is a consequence of climate change processes all over the Globe (IPCC, 2013). This problem, which generates pluvial flood hazard, is more pronounced in urban areas, especially in medium and large cities, as a consequence of old or underdeveloped water drainage systems (EEA, 2012). The same problem has been observed in Novi Sad, which is not only the second largest city in Serbia but also a historical city. There are several recurrent locations where pluvial floods occur after each extreme precipitation, i.e. traffic intersections, underpasses, streets, etc. Based on the multi-year monitoring of extreme rainfalls and pluvial floods in urban and suburban/rural areas of Novi Sad, it has been established that the average occurrence of pluvial flood events is four per year but it reached 11 in 2018 (internal documentation of the PUC Water and Sewage Utility Novi Sad). These extreme precipitation events and floods usually occur in spring and summer months, especially from the beginning of May until the end of August. For instance, the results from May 16th until August 26th, 2018, show that there were nine days when the amount of precipitation was higher than $20 \mathrm{~mm}$. This is also visible in Figure 2. Furthermore, spatial differences have been identified in the summer rainfall pattern. The stations recorded different values of precipitation depending on their location. A clear example for this is June 29th, 2018, 
when the amount of precipitation for the same event ranged between $15 \mathrm{~mm}$ and $94 \mathrm{~mm}(\mathrm{FU}-94 \mathrm{~mm}$; SA - $71 \mathrm{~mm}$; AD - $49 \mathrm{~mm}$; GC - $46 \mathrm{~mm}$; KA - 37; RP 27; SK $-16 \mathrm{~mm}$ ). Two relations appeared at $90 \%$ of acceptability for the CDD and Rp95 indices, and one relation at $95 \%$ for the CDD index. It shows a significant difference for these indices depending on the type of land cover across Novi Sad (between the urbanised and the non-urbanised group). In addition, few other indices were close to showing a difference, notably PRCPTOT, TP, R9op, and R99p. Generally, based on the obtained outcomes of precipitation indices, it can be concluded that during extreme precipitation or dry events there may be notable differences between urbanised and non-urbnised areas. These differences may most frequently occur in the summer period, when surface has an important role on the local weather (based on convective processes), i.e. on heavy precipitation events.

According to the present results, more relations could appear or some refinement of the acceptability threshold could be performed. To reach that goal, several factors could be developed or improved - namely: a) a denser monitoring network of precipitation stations would provide more accurate spatial tendencies; in Novi Sad, stations are mostly located in suburban/ rural areas and most of the urbanised parts of the Novi Sad are not adequately covered by the sensor network; b) the urban area of Novi Sad, as a medium-sized city covering about $102 \mathrm{~km} 2$, is probably not large enough to catch in details the real precipitation/rainfall differences between different land cover types and detect possible differences based on urbanisation types; c) it is better to analyse monitoring periods longer than four years, but in this study the time frame for precipitation measurements was determined by the onset of the network; d) it is important to ensure proper functioning of the gauge station, because of the incoherent values already obtained; in Novi Sad, the complete monitoring system is functioning since 2015; e) in addition to the elements mentioned, the analysis of the weather conditions and the movement of atmospheric masses should be useful in the process of establishing precipitation and pluvial flood issues.

The literature data on high-resolution precipitation monitoring confirm the previous statements through the analysis of the outcomes. Wang et al. (2018) conclude that urban environments probably play a positive role in generating short-term heavy precipitation through enhancing deep convections induced by higher surface temperatures and higher aerosol concentrations. The analysis of Wang et al. (2018) was based on high-resolution precipitation data and urban extent data in the Pearl River Delta (China). The extreme precipitation and the mean intensity were posi- tively correlated with urban extent, whereas wet hours were negatively correlated. According to Han et al. (2014), the effect of urban extent on precipitation can be studied in three different ways: a) urban heat island (UHI); b) urban surface roughness; and c) higher aerosol concentration. Furthermore, Han and Biak (2008) have found that UHI causes an upward motion downwind of the urban area, which partially explains the increasing precipitation in urbanized areas. Increased precipitation based on surface roughness and anthropogenic high aerosol concentration has also been detected by Cotton and Pielke (2007) and Rosenfeld et al. (2008). Burić and Doderović (2019) have found that the urban area of Podgorica has up to $100 \mathrm{~mm}$ higher annual rainfall, compared to the nonurban area. According to Wang et al. (2015), urban extent is strongly correlated to the maximum precipitation amount, whereas Shepherd (2005) has concluded that urban expansion plays an important role in shaping regional climate. Accordingly, the effect of urban extent on climate has become a major research focus in the previous decade, keeping also in mind the hazard of pluvial flood in urban areas. Research projects on this topic are also implemented in Central Europe. The URBAN-PREX is a project focusing on monitoring, forecasting and developing an online public early warning system for extreme precipitation and pluvial floods in the urban areas of the Hungarian-Serbian cross-border region. The measurement data from the two precipitation networks deployed in Novi Sad (Serbia) and Szeged (Hungary) will be used to fine-tune remotely sensed data, thereby enabling the development of a more precise two-day forecast model for the area covered by the research programme. The measurement and forecasting data are freely available in real-time on the project website, project social pages and a mobile Android application giving an early warning to citizens and public authorities in order to protect them and prepare an effective response to these extreme precipitation events and pluvial flood situations (Prokić et al., 2019). Other projects with a similar goal are being developed - e.g. the Amsterdam Rainproof project, seeking to make Amsterdam resistant to the increasingly frequent showers and make better use of the free rainwater drained through permeable paving, green roofs and façade gardens. In the United States, the INTENSE project has acquired data from more than 23,000 rain gauges from its global sub-daily rainfall dataset (GSDR) and has provided evidence of the intensification of hourly extreme precipitation (Blenkinsop et al., 2018).

Figure 3 presents the numerous risks and adverse effects posed by pluvial flooding that are the result of extreme and intensive precipitation/rainfall in urban and suburban/rural areas (Prokić et al., 2019). The 


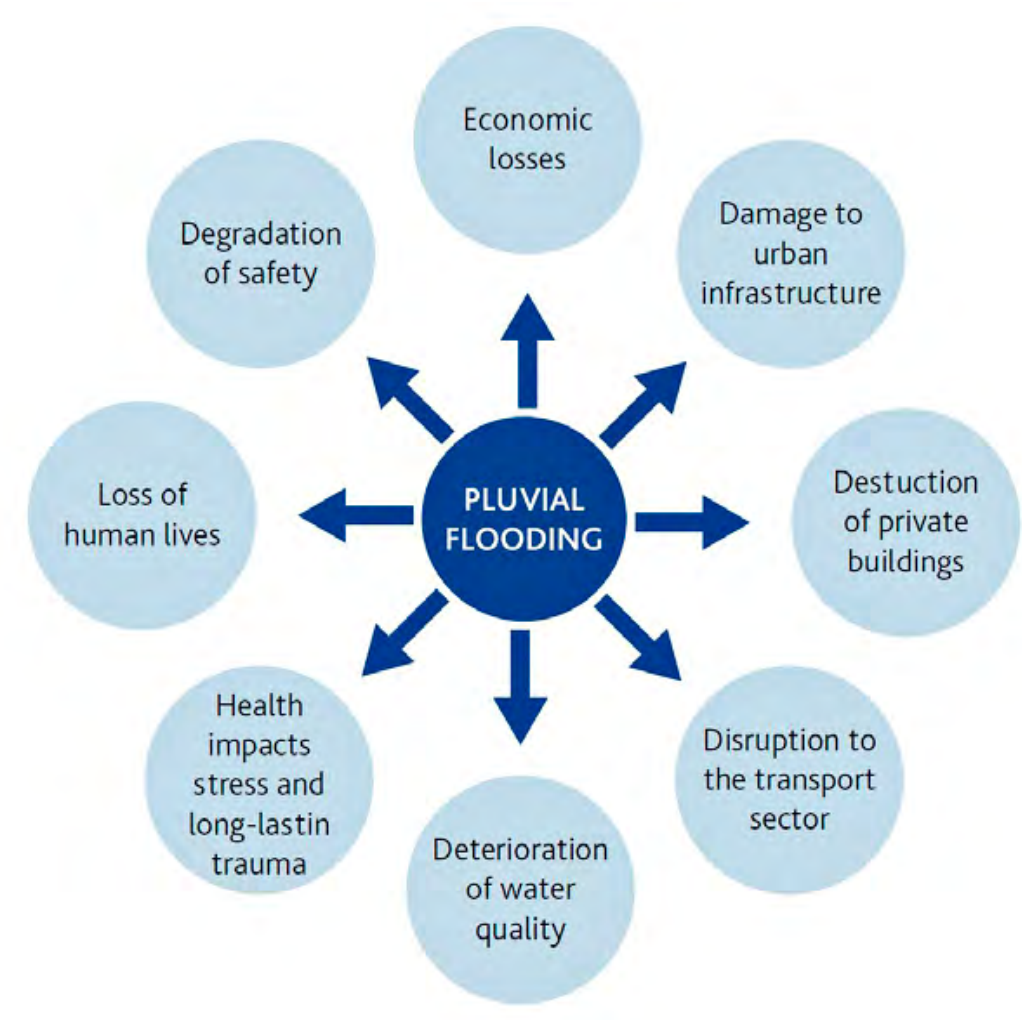

Figure 3. Risks associated with pluvial floods resulting from extreme and intensive precipitation/rainfall events across urban and suburban/rural areas Source: Prokić et al., 2019

direct and indirect impacts of extreme and intensive precipitation/rainfall include loss in economic terms, the damaging and destruction of private buildings and urban infrastructure, the loss of human lives, the degradation of safety (Sentić and Đorđević, 2019) and the deterioration of water quality (Szewrański et al., 2018a). Urban pluvial flooding is the predominant cause of weather-related disruptions to the transport sector (Pregnolato et al., 2017) and city traffic delays and inconvenience (Zhou et al., 2012). Examples of indirect effects include lost working hours and health impacts on affected residents, which may occur if sewer water flows onto streets or if pluvial flood water stands stagnant (Sušnik et al., 2014). The indirect impacts may occur beyond the location and time of flood events - e.g. long-lasting trauma and stress (Szewrański et al., 2018b). According to Gaume et al. (2009), pluvial floods are one of the most significant natural hazards in Europe, causing serious risk to life and infrastructure, namely the destruction of buildings. Finally, detailed and systematic research of extreme precipitation events and the resulting occurrence of pluvial floods could be, in the future, an important contribution to local communities towards devising measures for adaptation strategies and adequate protocols for mitigation action steps.

\section{Acknowledgements}

This research is supported by Interreg-IPA CBC Hungary-Serbia program through the project URBAN-PREX (ID: HUSRB/1602/11/oo97). The research presented in this paper is partially supported by the Ministry of Education, Science and Technological Development of the Republic of Serbia (Grant No. 451-03-68/2020-14/200125). The authors want to thank the PUC Water and Sewage Utility Novi Sad (JKP Vodovod i Kanalizacija Novi Sad) on provided precipitation data. Also, the authors would like to thank the Reviewers for useful tips in order to improve the article. 


\section{References}

Allen, M.R., de Coninck, H., Dube, O.P., Hoegh-Guldberg, O., Jacob, D., Jiang, K., Revi, A., Rogelj, J., Roy, J., Shindell, D., Solecki, W., Taylor, M., Tschakert, P., Waisman, H., Abdul Halim, S., Antwi-Agyei, P., Aragón-Durand, F., Babiker, M., Bertoldi, P., Bindi, M., Brown, S., Buckeridge, M., Camilloni, I., Cartwright, A., Cramer, W., Dasgupta, P., Diedhiou, A., Djalante, R., Dong, W., Ebi, K.L., Engelbrecht, F., Fifita, S., Ford, J., Forster, P., Fuss, S., Ginzburg, V., Guiot, J., Handa, C., Hayward, B., Hijioka, Y. Hourcade, J.-C., Humphreys, S., Kainuma, M., Kala, J., Kanninen, M., Kheshgi, H., Kobayashi, S., Kriegler, E., Ley, D., Liverman, D., Mahowald, N., Mechler, R., Mehrotra, S., Mulugetta, Y., Mundaca, L., Newman, P., Okereke, C., Payne, A., Perez, R., Pinho, P.F., Revokatova, A., Riahi, K., Schultz, S., Séférian, R., Seneviratne, S.I., Steg, L., Suarez Rodriguez, A.G., Sugiyama, T., Thomas, A., Vilariño, M.V., Wairiu, M., Warren, R., Zickfeld, K., \& Zhou, G. (2018). Technical Summary. In: Global Warming of $1.5^{\circ} \mathrm{C}$. An IPCC Special Report on the impacts of global warming of $1.5^{\circ} \mathrm{C}$ above pre-industrial levels and related global greenhouse gas emission pathways, in the context of strengthening the global response to the threat of climate change, sustainable development, and efforts to eradicate poverty (V., Masson-Delmotte, P. Zhai, H.-O. Pörtner, D. Roberts, J. Skea, P.R. Shukla, A. Pirani, W. MoufoumaOkia, C. Péan, R. Pidcock, S. Connors, J.B.R. Matthews, Y. Chen, X. Zhou, M.I. Gomis, E. Lonnoy, T. Maycock, M. Tignor, and T. Waterfield (eds.)). In Press.

Blenkinsop, S., Fowler, H.J., Berbero, R., Chan, S.C., Buerreiro, S.B., Kendon, E., Lenderink, G., Lewis, E., Li, X-F., Westra, S., Alexander, L., Allan, R.P., Berg, P., Dunn, R.J.H., Ekström, M., Evans, J.P., Holland, G., Jones, R., Kjellström, E., Klein-Tank, A., Lettenmaier, D., Mishra, V., Prein, A.F., Sheffield, J., \& Tye, M.R. (2018). The INTENSE project: using observations and models to understand the past, present and future of sub-daily rainfall extremes. Advances in Science \& Research, 15, 117-126. DOI:10.5194/asr-15-117-2018

Borga, M., Tonelli, F., Moore, R.J., \& Andrieu, H. (2002). Long-term assessment of bias adjustment in radar rainfall estimation. Water Resources Research, 38(11), 8-1-8-10. DOI:10.1029/2001wrooo555

Burić, D., \& Doderović, M. (2019). Precipitation, humidity and cloudiness in Podgorica (Montenegro) during the period 1951-2018. Geographica Pannonica, 23(4), 233-244. DOI: 10.5937/gp23-23582
Ciscar, J.-C., Iglesias, A., Feyen, L., Szabo, L., Van Regemorter, D., Amelung, B., Nicholls, R., Watkiss, P., Christensen, O.B., Dankers, R., Garrote, L., Goodess, C.M., Hunt, A., Moreno, A., Richards, J., \& Soria, A. (2011). Physical and economic consequences of climate change in Europe. Proceedings of the National Academy of Sciences, 108(7), 2678-2683. DOI:10.1073/pnas.1011612108

Collier, C. (2007). Flash flood forecasting: What are the limits of predictability? Quarterly Journal of the Royal Meteorological Society, 133(622), 3-23. DOI:10.1002/qj.29

Cotton, W.R., \& Pielke, R.A. (2007). Human Impacts on Weather and Climate. Cambridge, UK: Cambridge University Press, $296 \mathrm{pp}$.

EEA (2012). Urban adaptation to climate change in Europe - Challenges and opportunities for cities together with supportive national and European policies. European Environment Agency, Report no. 2/2012, Copenhagen, Denmark, 143 pp.

Gaume, E., Bain, V., Bernardara, P., Newinger, O., Barbuc, M., Bateman, A., Blaškovicová, L., Blöschl, G., Borga, M., Dumitrescu, A., Daliakopoulos, I., Garcia, J., Irimescu, A., Kohnova, S., Koutroulis, A., Marchi, L., Matreata, S., Medina, V., Preciso, E., Sempere-Torres, D., Stancalie, G., Szolgay, J., Tsanis, I., Velasco, D., \& Viglione, A. (2009). A compilation of data on European flash floods. Journal of Hydrology, 367, 70-78. DOI:10.1016/j.jhydrol.2008.12.028

Geletič, J., \& Lehnert, M. (2016). GIS-based delineation of local climate zones: The case of mediumsized Central European cities. Moravian Geographical Report, 24(3), 2-12. DOI:10.1515/mgr-2016-0012

Geletič, J., Lehnert, M., Savić, S., \& Milošević, D. (2019). Inter-/intra-zonal seasonal variability of the surface urban heat island based on local climate zones in three central European cities. Building and Environment, 156, 21-32. DOI:10.1016/j.buildenv.2019.04.011

Groisman, P.Y., Knight, R.W., Karl, T.R., Easterling, D.R., Sun, B., \& Lawrimore, J.H. (2004). Contemporary Changes of the Hydrological Cycle over the Contiguous United States: Trends Derived from In Situ Observations. Journal of Hydrometeorology, 5(1), 64-85. DOI:https://doi.org/10.1175/15257541(2004)005<0064:CCOTHC>2.0.CO;2

Groisman, P.Y., Knight, R.W., Easterling, D.R., Karl, T.R., Hegerl, G.C., \& Razuvaev, V.N. (2005). Trends in Intense Precipitation in the Climate Record. Journal of Climate, 18(9), 1326-1350. DOI:https://doi. org/10.1175/JCLI3339.1 
Guerreiro, S.B., Glenis, V., Dawson, RJ., \& Kilsby, C. (2017). Pluvial flooding in European cities - A continental approach to urban flood modelling. Water, 9(4), 296. DOI:10.3390/w9040296

Han, J.Y., \& Baik, J.J. (2008). A theoretical and numerical study of urban heat island-induced circulation and convection. Journal of the Atmospheric Sciences, 65(6), 1859-1877. DOI:10.1175/2007JAS2326.1

Han, J.Y., Baik, J.J., \& Lee, H. (2014). Urban impacts on precipitation. Asia-Pacific Journal of Atmospheric Sciences, 50(1), 17-30. DOI:10.1007/s13143-014-0016-7

IPCC (2007). Climate Change 2007: Impacts, Adaptation and Vulnerability. (M.L. Parry, O.F. Canziani, J.P. Paultikof, P.J. van der Linden and C.E. Hanson, (eds.)). Contribution of Working Group II to the Fourth Assessment Report of the Intergovernmental Panel on Climate Change. Cambridge, UK: Cambridge University Press, 976 pp.

IPCC (2013). Climate Change 2013: The Physical Science Basis. (T.F. Stocker, D. Qin, G.-K. Plattner, M. Tignor, S.K. Allen, J. Boschung, A. Nauels, Y. Xia, V. Bex and P.M. Midgley (eds.)). Contribution of Working Group I to the Fifth Assessment Report of the Intergovernmental Panel on Climate Change Cambridge, United Kingdom and New York, NY, USA: Cambridge University Press, 1535 pp.

Jiang, Y., Zevenbergen, C., \& Ma, Y. (2018). Urban pluvial flooding and stormwater management: A contemporary review of China's challenges and "sponge cities" strategy. Environmental Science \& Policy, 80, 132-143. DOI:10.1016/j.envsci.2017.11.016

Karl, T.R., Nicholls, N., \& Ghazi, A. (1999). CLIVAR/ GCOS/WMO workshop on indices and indicators for climate extremes: Workshop summary. Climate Change, 42, 3-7.

Kottek, M., Grieser, J., Beck, C., Rudolf, B., \& Rubel, F. (2006). World Map of the Koppen-Geiger climate classification updated. Meteorologische Zeitschrift, 15(3), 259-263. DOI:10.1127/0941-2948/2006/0130

Lelovics, E., Unger, J., Savić, S., Gál, T., Milošević, D., Gulyás, Á., Marković, V., Arsenović, D., \& Gál, C.V. (2016). Intra-urban temperature observations in two Central European cities: a summer study. Idojaras, 120(3), 283-300.

Marchi, L., Borga, M., Preciso, E., \& Gaume, E. (2010). Characterisation of selected extreme flash floods in Europe and implications for flood risk management. Journal of Hydrology, 394(1-2), 118-133. DOI:10.1016/j.jhydrol.2010.07.017

Milošević, D., \& Savić, S. (2013). Analysis of precipitation quantities and trends from Pannonian and Peripannonian parts of Serbia. Dela, 39, 125-139. DOI:10.4312/dela.39.7.125-139

Neppel, L., Desbordes, M., \& Masson, J.M. (1997). Spatial extension of extreme rainfall events: return pe- riod of isohyets area and influence of rain gauges network evolution. Atmospheric Research, 45(3), 183-199. DOI:10.1016/s0169-8095(97)00038-o

Pregnolato, M., Ford, A., Wilkinson, S.M., \& Dawson, R.J. (2017). The impact of flooding on road transport: A depth-disruption function. Transportation Research Part D: Transport and Environment, 55, 67-81. https://doi.org/10.1016/j.trd.2017.06.020

Prokić, M., Savić, S., \& Pavić, D. (2019). Pluvial flooding in urban areas across the European continent. Geographica Pannonica, 23(4), 216-232. DOI:10.5937/ gp23-23508

Richard, M.J. (2002). The State of the World Cities Report 2001/Cities in a Globalizing World : Global Report on Human Settlements 2001. Journal of the American Planning Association, 68(3), 336.

Rosenfeld, D., Lohman, U., Raga, G.B., O’Dowd, C.D., Kulmala, M., Fuzzi, S., Reissell, A., \& Andreae, M.O. (2008). Flood or drought: how do aerosols affect precipitation? Science, 321, 1309-1313. DOI:10.1126/ science.1160606

Sentić, I., \& Đorđević, T. (2019). Understanding physical environment through safe highway transport mobility with special review on climate - the highway route Belgrade-Novi Sad, Serbia. Geographica Pannonica, 23(1), 1-13. DOI:10.5937/gp23-19285

Shepherd, J.M. (2005). A review of current investigations of urban-induced rainfall and recommendations for the future. Earth Interactions, 9(1)2, 1-27. DOI:10.1175/EI156.1

Stewart, I.D., \& Oke, T.R. (2012). Local Climate Zones for urban temperature studies. Bulletin of the American Meteorological Society, 93, 1879-1900. DOI:10.1175/BAMS-D-11-00019.1

Sušnik, J., Strehl, C., Postmes, L.A., VamvakeridouLyroudia, L.S., Maelzer, H.J., Savic, D.A., \& Kapelan, Z. (2014). Assessing Financial Loss due to Pluvial Flooding and the Efficacy of Risk-Reduction Measures in the Residential Property Sector. Water Resources Management, 29. DOI: 10.1007/ s11269-014-0833-6

Swart, R., Fons, J., Geertsema, W., van Hove, B., Gregor, M., Havranek, M., Jacobs, C., Kazmierczak, A., Krellenberg, K., Kuhlicke, C., \& Peltonen, L. (2012). Urban vulnerability indicators. ETCCCA and ETC-SIA Technical Report 01/2012, UK, pp. 178.

Szewrański, S., Chruściński, J., van Hoof, J., Kazak, J., Malgorzata, S., Tokarczyk-Dorociak, K., \& Żmuda, R. (2018a). A Location Intelligence System for the Assessment of Pluvial Flooding Risk and the Identification of Storm Water Pollutant Sources from Roads in Suburbanised Areas. Water, 10(6), 746. DOI :10.3390/w10060746 
Szewrański, S., Chruściński, J., van Hoof, J., Kazak, J., Malgorzata, S., Tokarczyk-Dorociak, K., \& Żmuda, R. (2018b). Pluvial Flood Risk Assessment Tool (PFRA) for Rainwater Management and Adaptation to Climate Change in Newly Urbanised Areas. Water, 10(4), 386. DOI: 10.3390/w10040386

Trobec, T. (2017). Frequency and seasonality of flash floods in Slovenia. Geographica Pannonica, 21(4), 198-211. DOI:10.5937/gp21-16074

UNFPA (1999). The State of World Population 1999: 6 Billion - A time for Choices. New York, USA: United Nations Population Fund, 76 pp.

Xia, J., Zhang, Y., Xiong, L., He, S., Wang, L., \& Yu, Z. (2017). Opportunities and challenges of the Sponge City construction related to urban water issues in China. Science China Earth Sciences, 6o(4), 652658. DOI:10.1007/s11430-016-0111-8

Wang, D., Jiang, P., Wang, G., \& Wang, D. (2015). Urban extent enhances extreme precipitation over the Perl River Delta. Atmospheric Science Letters, 16, 310-317. DOI:10.1002/asl2.559
Wang, D., Wang, D., Qi, X., Liu, L., \& Wang, X. (2018). Use of high-resolution precipitation observations in quantifying the effect of urban extent on precipitation characteristics for different climate conditions over the Perl River Delta, China. Atmospheric Science Letters, 19, e820. DOI:10.1002/asl.820

WMO (2008). Urban flood risk management - A tool for integrated flood management. Associated Programme on Flood Management, World Meteorological Organization, APFM Technical Document no. $11,38 \mathrm{pp}$.

Zhang, X., Alexander, L., Hegerl, G.C., Jones, P., Tank, A.K., Peterson, T.C., Trewin, B., \& Zwiers, T.W. (2011). Indices for monitoring changes in extreme based on daily temperature and precipitation data. WIREs Climate Change, 2, 851-870. DOI:10.1002/wwc.147

Zhou, Q., Mikkelsen, P.S., Halsnæs, K., \& ArnbjergNielsen, K. (2012). Framework for economic pluvial flood risk assessment considering climate change effects and adaptation benefits. Journal of Hydrology, 414-415, 539-549. https://doi.org/10.1016/j.jhydrol.2011.11.031 